\title{
Cross-species transferability of eastern white pine (Pinus strobus) nuclear microsatellite markers to five Mexican white pines
}

\author{
A.R. Villalobos-Arámbula ${ }^{1}$, J.A. Pérez de la Rosa ${ }^{2}$, A. Arias ${ }^{2}$, O.P. Rajora ${ }^{3}$ \\ ${ }^{1}$ Departamento de Biología Celular y Molecular, Universidad de Guadalajara, \\ Zapopan, México \\ ${ }^{2}$ Departamento de Botánica y Zoología, Universidad de Guadalajara, \\ Zapopan, México \\ ${ }^{3}$ Canadian Genomics and Conservation Genetics Institute, \\ Faculty of Forestry and Environmental Management, \\ University of New Brunswick, Fredericton, Canada \\ Corresponding author: A.R. Villalobos-Arámbula \\ E-mail: avillal@cucba.udg.mx / alma.villal@gmail.com
}

Genet. Mol. Res. 13 (3): $7571-7576$ (2014)

Received July 24, 2013

Accepted June 20, 2014

Published September 12, 2014

DOI http://dx.doi.org/10.4238/2014.September.12.24

ABSTRACT. We examined cross-species transferability and usefulness of six nuclear microsatellite markers developed in consubgeneric eastern white pine (Pinus strobus) with regard to ecologically and commercially important Mexican white pine species of conservation genetics concern: Pinus chiapensis (Mart.) Andresen, P. flexilis James, $P$. strobiformis Engelm., P. ayacahuite Ehrenb. Ex Schltdl, and $P$. ayacahuite var. veitchii (Roezl) G.R. Shaw. Four to six microsatellite loci were found to be polymorphic in different species, with moderate to high informativeness in a relatively small number of samples $\left(\mathrm{PIC} / H_{\mathrm{E}}\right.$ $=0.25-0.93$ ). This successful transfer sidesteps the time- and resourceconsuming development of species-specific microsatellite markers, and will facilitate population and conservation genetic studies and genetic 
resource management of the less studied Mexican white pines.

Key words: Cross-species transferability; Eastern white pine; Mexican white pines; Nuclear microsatellite markers

\section{INTRODUCTION}

Mexican white pines represent a valuable natural resource because they play an essential role in ecological processes and are an important source of timber and cellulose (Farjon and Styles, 1997). The main Mexican white pine species are: Pinus chiapensis (Mart.) Andresen, P. flexilis James, P. strobiformis Engelm., P. ayacahuite Ehrenb. Ex Schltdl, and P. ayacahuite var. veitchii (Roezl) G.R. Shaw. They belong to the subgenus Strobus of the genus Pinus. The conservation genetics of most of these species is important (Bower et al., 2011). Despite the ecological, conservation, and economic importance of these Mexican white pines, very few studies have been conducted regarding their genetic diversity and population structure, which would facilitate the conservation and sustainable management of their genetic resources. This is probably due to the almost complete lack of highly informative cross-species transferable DNA markers of the nuclear genome. Pinus chiapensis is perhaps the most studied of the Mexican white pines. Published molecular studies based on isozymes and DNA markers (low-copy unlinked nuclear loci and RAPDs) revealed low genetic diversity in this species (Castillo et al., 2009). Molecular marker-based studies in the P. strobiformis-P. ayacahuite complex have been limited to genetic diversity assessment using isozymes (Hernández-Gónzalez 1990; Ledig, 1998), RAPDs (Castro-Félix et al., 2006), and chloroplast microsatellite markers (Ortíz-Medrano et al., 2008; Moreno-Letelier and Piñero, 2009).

Microsatellites or simple sequence repeats (SSRs) provide a rich source of highly informative codominant genetic markers that are suitable for a variety of genetics and breeding studies and applications. Recently, next-generation sequencing of genomic and cDNA allows the identification of large numbers of microsatellites. However, all of the approaches require library construction and sequencing efforts, which are still not affordable or feasible in laboratories with scarce resources, especially in developing countries such as Mexico. In such cases, cross-species transferability of microsatellite markers between phylogenetically close species could serve as an adequate interim strategy, particularly when the objective is only to find a limited number of markers to conduct population and conservation genetic studies (Dayananadan et al., 1998; Rajora et al., 2001; Echt et al., 2011).

The objective of this study was to examine the transferability of nuclear microsatellite markers developed in eastern white pine (Pinus strobus) (Echt et al., 1996) to Mexican white pine species and their informativeness. The microsatellite loci were selected on the basis of the level of polymorphism detected in P. strobus in previous studies (Echt et al., 1996; Rajora et al., 2000; Marquardt and Epperson, 2004).

\section{MATERIAL AND METHODS}

Four Mexican white pine species, including two varieties of one species were used to examine the transferability and informativeness of eastern white pine microsatellites: Pinus chiapensis - Chiapas pine, P. flexilis -limber pine, P. strobiformis - southwestern white pine/ Mexican white pine, $P$. ayacahuite - Mexican white pine, and $P$. ayacahuite var. veitchii. Two to 15 accessions per species or variety were used (Table 1). The individuals used for this study 


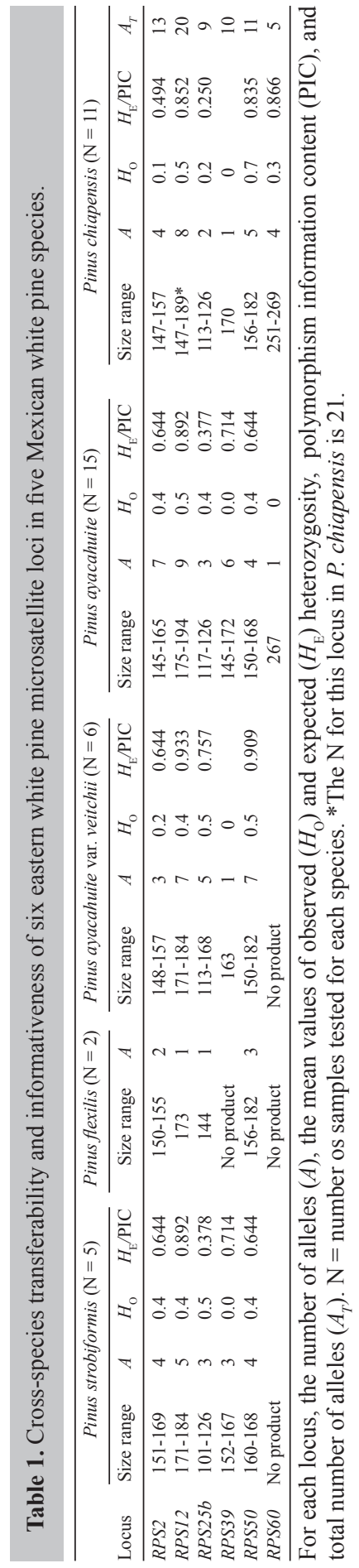


were sampled from the following natural populations in México: P. strobiformis $\left(31^{\circ} 03^{\prime} 18^{\prime}\right.$

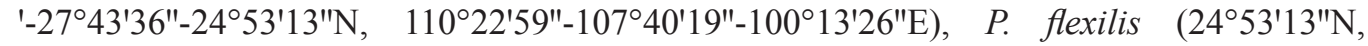
$\left.100^{\circ} 13^{\prime} 26^{\prime \prime E}\right), P$. ayacahuite $\left(20^{\circ} 09^{\prime} 26^{\prime \prime}\right.$ topotype-20 $09^{\prime} 13^{\prime \prime}-19^{\circ} 31^{\prime} 08^{\prime \prime}-16^{\circ} 40^{\prime} 13^{\prime \prime N}, 98^{\circ} 39^{\prime} 20^{\prime}$ '-98 $\left.38^{\circ} 07^{\prime \prime}-97^{\circ} 05^{\prime} 42^{\prime \prime} 92^{\circ} 33^{\prime} 15^{\prime \prime} \mathrm{E}\right)$, P. ayacahuite var. veitchii $\left(20^{\circ} 22^{\prime} 41^{\prime \prime}-19^{\circ} 40^{\prime}-19^{\circ} 12^{\prime} 38^{\prime}\right.$ 'N, $\left.105^{\circ} 02^{\prime} 37^{\prime \prime}-102^{\circ} 25^{\prime}-98^{\circ} 44^{\prime} 10^{\prime \prime} \mathrm{E}\right)$, and P. chiapensis $\left(19^{\circ} 55^{\prime} 17^{\prime \prime}-16^{\circ} 59^{\prime} 49^{\prime \prime} \mathrm{N}, 97^{\circ} 15^{\prime} 26^{\prime \prime}-\right.$ $\left.92^{\circ} 49^{\prime} 41^{\prime \prime E}\right)$.

Total genomic DNA was extracted from needles of individual sampled trees using the CTAB method with minor modifications (Palomera et al., 2008). DNA quality and concentration were determined visually on agarose gels and by UV spectrophotometry. DNA samples were diluted in MilliQ water to a final concentration of $20 \mathrm{ng} / \mu \mathrm{L}$.

Six microsatellite loci (RPS2, RPS12, RPS25b, RPS39, RPS50 and RPS60) developed and characterized by Echt et al. (1996) were used to test their transferability and informativeness in Mexican white pines. These markers were selected from the 12 polymorphic SSRs used for genetic diversity assessment in eastern white pine by Rajora et al. (2000) because of their high polymorphism. The PCR amplification of the microsatellites in the Mexican pine samples was performed according to Rajora et al. (2000) with minor modifications. PCR amplifications were carried out using $10-\mu \mathrm{L}$ reaction mixtures containing 20 ng genomic DNA, 1X PCR buffer, $2.5 \mathrm{mM} \mathrm{MgCl}, 0.25 \mathrm{mM}$ of each dNTP, $250 \mathrm{nM}$ each primer and $0.15 \mathrm{U}$ Taq DNA polymerase (Invitrogen, USA). PCR products were separated on a LI-COR 4200 genetic analyzer, and the alleles at a SSR locus were determined by scoring the LI-COR gels with the SAGA GT program (LI-COR Inc. Lincoln, NE, USA) and verified manually. We tested each SSR locus for successful amplification on DNA from each species in only one individual PCR run. The number of alleles was determined for each locus. The observed and expected heterozygosities were estimated using ARLEQUIN v3.5 (Excoffier and Lischer 2010). The polymorphism information content (PIC) of each locus was determined as described by Cuc et al. (2008).

$$
\mathrm{PIC}=1-\sum P_{\mathrm{i}}^{2}
$$

where $P_{\mathrm{i}}$ is the frequency of the $i$ th allele in the species examined. This value is the same as expected heterozygosity $\left(H_{\mathrm{E}}\right)$.

\section{RESULTS AND DISCUSSION}

The results of the cross-species amplification, transferability, and informativeness of six microsatellite markers in the Mexican white pine species studied are shown in Table 1. The primers of all six SSR loci produced amplification products in the expected size range. All six microsatellite loci were resolved in P. chiapensis and P. ayacahuite; however, RPS39 was monomorphic in $P$. chiapensis and RPS60 was monomorphic in $P$. ayacahuite (Table 1). Five microsatellite loci were resolved in each of $P$. strobiformis and $P$. ayacahuite var. veitchii, and four in P. flexilis (Table 1). The primers for RPS60 did not produce any amplicons in these three Mexican white pine taxa. Loci RPS12 and RPS25b were monomorphic in P. flexilis with limited sample size of 2 . The number of alleles at a polymorphic locus ranged from 2 at RPS25b in P. chiapensis to 9 at RPS12 in P. ayacahuite. The total number of alleles at a locus ranged from 5 to 20 across all species, with RPS12 showing the highest, 20 alleles. The $\mathrm{PIC} / H_{\mathrm{E}}$ ranged from 0.25 at RPS25b in P. chiapensis to 0.93 at RPS12 in P. ayacahuite var. 
veitchii (Table 1). Overall, the SSR markers showed high informativeness despite the very small sample size used. This informativeness is similar to that normally observed in a source species of microsatellites. Cross-species amplification of all six eastern white pine microsatellites and high informativeness of the polymorphic markers in P. chiapensis is consistent with very close phylogenetic relationships between these two species as compared to eastern white pine's relationships with other Mexican white pine species examined in this study (Gernandt et al., 2005; Parks et al., 2009).

The results of our study demonstrate that four to six microsatellite markers developed and characterized in eastern white pine are transferable to and informative in the five Mexican white pine species and varieties examined. These markers could be used for various population and conservation genetic studies, as well as others, and in applications in the Mexican pines examined. The informativeness of these markers will likely be higher than those observed in our study because the sample size used was very small. The other microsatellite markers developed in eastern white pine (Echt et al., 1996), especially those that have been successfully used in population and conservation genetic studies in eastern white pine (Rajora et al., 2000; Marquardt and Epperson, 2004), should be examined for their cross-species transferability and informativeness in the Mexican white pine species studied.

\section{ACKNOWLEDGMENTS}

Research supported by the SEP-CONACYT (\#33129-B), the PIFI (\#2012-UDGCA-44) and PROMEP (2013 Apoyo para Gastos Publicacións), as well as the Natural Sciences and Engineering Research Council of Canada (NSERC) (Discovery Grant \#RGPIN 170651 to O.P. Rajora). The laboratory research was conducted at Dalhousie University in the Forest Genetics and Biotechnology Laboratory of Dr. Om Rajora. Jesús Aguirre and JS Sierra provided valuable suggestions.

\section{REFERENCES}

Bower AD, McLane SC, Eckert A and Jorgensen S (2011). Conservation Genetics of High Elevation Five-Needle White Pines. In: The Future of High-Elevation Five-Needled White Pines in Western North America. Proceedings of High Five Symposium, June 28-30, 2010 (Keane RE, Tomback DE, Murray MP and Smith CM, eds.). US Department of Agriculture, Forest Service, Rocky Mountain Research Station., Missoula, 98-117.

Castillo RF, Trujillo S and Sáenz-Romero C (2009). Pinus chiapensis, a keystone species: Genetics, ecology, and conservation. Forest Ecol. Manag. 257: 2201-2208.

Castro-Félix P, Ramos C, Pérez de la Rosa JA and Vargas G (2006). Diversidad genética de Pinus ayacahuite utilizando marcadores RAPDs en genoma diploide y haploide. Sci. CUCBA 8: 193-202.

Cuc LM, Mace ES, Crouch JH, Quang VD, et al. (2008). Isolation and characterization of novel microsatellite markers and their application for diversity assessment in cultivated groundnut (Arachis hypogaea). BMC Plant Biol. 8: 55.

Dayanandan S, Rajora OP and Bawa KS (1998). Isolation and characterization of microsatellites in trembling aspen (Populus tremuloides). Theor. Appl. Genet. 96: 950-956.

Echt CS, Saha S, Deemer DL and Nelson D (2011). Microsatellite DNA in genomic survey sequences and UniGenes of loblolly pine. Tree Genet. Genomes 7: 773-780.

Echt CS, May-Marquardt P, Hseih M and Zahorchak R (1996). Characterization of microsatellite markers in eastern white pine. Genome 39: 1102-1108.

Excoffier L and Lischer HE (2010). Arlequin suite ver 3.5: a new series of programs to perform population genetics analyses under Linux and Windows. Mol. Ecol. Resour. 10: 564-567.

Farjon A and Styles BT (1997). Pinus (Pinaceae) Flora Neotropica. Monograph 70. New York Botanical Garden, New York. 
Gernandt DS, Lopez GG, Garcia SO and Liston A (2005). Phylogeny and classification of Pinus. Taxon 54: 29-42.

Hernández-Gónzález JJ (1990). Variación Genética Isoenzimática en Pinus ayacahuite y Sus Dos Variedades de México y Centroamérica. Master's Thesis. Universidad Autónoma Chapingo, Chapingo.

Ledig FT (1998). Genetic Variation in Pinus. In: Ecology and Biogeography of Pinus (Richardson DM, ed.). Cambridge University Press, Cambridge, 251-280.

Marquardt PE and Epperson BK (2004). Spatial and population genetic structure of microsatellites in white pine. Mol. Ecol. 13: 3305-3315.

Moreno-Letelier A and Piñero D (2009). Phylogeographic structure of Pinus strobiformis Engelm. across the Chihuahuan Desert filter-barrier. J. Biogeogr. 36: 121-131.

Ortíz-Medrano A, Moreno-Letelier A and Piñero D (2008). Fragmentación y expansión demográfica en las poblaciones mexicanas de Pinus ayacahuite var. ayacahuite. Bol. Soc. Bot. Méx. 83: 25-36.

Palomera V, Castro-Félix P and Villalobos-Arámbula AR (2008). High yield of high quality DNA from vegetative and sexual tissues of Mexican white pine (Pinus ayacahuite). Afr. J. Biotechnol. 7: 51-54.

Parks M, Cronn R and Liston A (2009). Increasing phylogenetic resolution at low taxonomic levels using massively parallel sequencing of chloroplast genomes. BMC Biol. 7: 84 .

Rajora OP, Rahman MH, Buchert GP and Dancik BP (2000). Microsatellite DNA analysis of genetic effects of harvesting in old-growth eastern white pine (Pinus strobus) in Ontario, Canada. Mol. Ecol. 9: 339-348.

Rajora OP, Rahman MH, Dayanandan S and Mosseler A (2001). Isolation, characterization, inheritance and linkage of microsatellite DNA markers in white spruce (Picea glauca) and their usefulness in other spruce species. Mol. Gen. Genet. 264: 871-882. 